Volume 5 Issue 2, 2019

P-ISSN : 2528-360X, E-ISSN : 2621-6159

Website: https://www.jurnal-umbuton.ac.id/index.php/Pencerah

\title{
Desain Silabus Bahasa Inggris Bagi Mahasiswa Jurusan Analis Kesehatan Poltekkes Kemenkes Kendari
}

\author{
1 Aswiro Hasan
}

\begin{abstract}
In preparing students for global professional communication, it is crucial to conduct an analysis related to teaching material, methods and context in which English are used. This study aims to design syllabi and teaching materials based on student needs. This research is a type of descriptive research. More accurate information about student needs is obtained through the provision of questionnaires and semistructured interviews to students, alumni, and lecturers. Data were analyzed using quantitative and qualitative methods. The findings of this study reveal the need to establish learning that focuses on the target context of the Medical laboratory technologist either for academic or professional development. The contents of the syllabus needed by students are a series of aspects of language skills namely reading and speaking provided with topics of Medical laboratory and grammar that are appropriate to the context and presented in a series of varied learning activities that can provide convenience in the process of language acquisition in the classroom.

Keywords: Need Analysis, Student Needs, English for Specific Purposes

\section{Abstrak}

Dalam menyiapkan mahasiswa menghadapi dunia komunikasi professional sangat perlu dilakukan sebuah analisis terkait materi ajar, metode, dan konteks dimana Bahasa inggris yang mereka pelajari akan digunakan. Penelitian ini bertujuan untuk merancang silabus dan materi ajar berdasarkan kebutuhan mahasiswa. Penelitian ini merupakan jenis penelitian deskriptif. Informasi yang lebih akurat mengenai kebutuhan mahasiswa diperoleh melalui pemberian angket dan wawancara semi terstruktur kepada mahasiswa, alumni, dan dosen. Data dianalisis dengan menggunakan metode kuantitatif dan kualitatif. Temuan penelitian ini mengungkapkan adanya kebutuhan untuk menetapkan pembelajaran yang berfokus pada konteks sasaran yakni disiplin sebagai tenaga laboratorium kesehatan untuk pengembangan akademik dan profesi. Isi silabus yang dibutuhkan oleh mahasiswa adalah rangkaian dari aspek keterampilan berbahasa yakni membaca dan berbicara diberikan dengan topik laboratorium kesehatan dan tata bahasa yang sesuai dengan konteks serta disajikan dalam rangkaian aktivitas belajar variatif yang dapat memberikan kemudahan dalam proses pemerolehan bahasa di dalam kelas.

Kata Kunci: Analisis Kebutuhan, Kebutuhan Mahasiswa, Bahasa Inggris untuk Tujuan Spesifik
\end{abstract}

\section{PENDAHULUAN}

Dalam persaingan global sekarang ini mahasiswa dituntut untuk dapat menguasai keterampilan berkomunikasi. Pemerintah menetapkan bahwa Bahasa inggris menjadi satu-satunya Bahasa internasional yang dipelajari sebagai mata pelajaran wajib di tingkat sekolah menengah dan perguruan tinggi. Pada tingkat perguruan tinggi mahasiswa diajarkan Bahasa inggris yang lebih spesifik pada tujuan atau yang lebih dikenal sebagai English for Specific Purposes (ESP). Sangat jelas ketika Bahasa inggris diajarkan untuk tujuan spesifik maka kurikulum dan bahan ajar harus disusun berdasarkan kebutuhan siswa itu sendiri. Analisis kebutuhan ini menjadi suatu karakter

${ }^{1}$ Poltekes Kemenkes Kendari, email: aswirohasan@gmail.com 
dalam mengambangkan kelas ESP di dunia, termasuk tenaga laboratorium kesehatan sebagai obyek dalam penelitian ini. Menurut Richards dan Schmidt, (2010:198) ESP merupakan pengajaran bahasa inggris dimana konten dan tujuannya tergantung oleh kebutuhan dari kelompok siswa tertentu. Materi yang disampaikan harus sesuai dengan konteks yang akan mereka hadapi dalam dunia kerjanya. Tentunya dalam merancang bahan ajar dan silabus ESP ini para desainer diharapkan sudah mengetahui latar belakang mahasiswanya, apa yang mereka dapat lakukan, apa yang mereka telah pelajari, dan apa yang mereka ingin pelajari, jadi dengan melaksanakan analisis kebutuhan ini desainer akan lebih jelas mengetahui keterampilan dan pengetahuan apa yang dibutuhkan oleh pembelajarnya dalam dalam situasi sasaran

Poltekkes Kemenkes Kendari merupakan sekolah vokasi yang terdiri dari 4 jurusan salah satunya adalah jurusan Analis Kesehatan. Sejauh ini Bahasa inggris diajarkan mengikuti kurikulum institusi yang masih umum dan belum merujuk pada suatu kompetensi khusus yang lebih relevan dengan minat mereka sehingga dosen mengajarkan materi Bahasa inggris yang lebih umum. Akibatnya, materi yang disajikan tidak berkontribusi banyak terhadap kebutuhan mahasiswa karena tidak secara langsung berhubungan dengan konteks dan minat belajar mereka. Untuk memenuhi kebutuhan mahasiswa perlu dilakukan penyusunan syllabus dan materi ajar yang terstruktur dengan baik dan memenuhi standar kebutuhan institusi
Dengan belum adanya silabus dan materi ajar yang sesuai dengan kebutuhan mahasiswa Analis Kesehatan Poltekkes Kemenkes Kendari maka dianggap dapat menjadi masalah ketika mereka menghadapi dunia kerja. Berdasarkan hal di atas maka pengembangan silabus dan materi ajar mata kuliah bahasa inggris yang berdasarkan kebutuhan mahasiswa sangat penting dan harus dilakukan.

\section{METODE PENELITIAN}

Penelitian ini adalah penelitian deskriptif kualitatif dengan tujuan untuk mengetahui kebutuhan belajar mahasiswa Jurusan Analis Kesehatan Poltekkes Kemenkes Kendari yang dilakukan pada bulan Agustus dan September 2018 bertempat di Jurusan Analis Kesehatan Poltekkes Kemenkes Kendari. Populasi merupakan sampel penelitian ini yaitu mahasiswa Jurusan Analis Kesehatan Poltekkes Kemenkes Kendari tahun akademik 2018-2016 dengan jumlah populasi 145 Mahasiswa. Data juga diperoleh dari dosen dan alumni dengan menggunakan dua model penentuan sampel yaitu random dan purposive sampling.

Beberapa kriteria yang digunakan untuk menentukan sampel. Menurut Brown (1995:37), ada 3 kelompok yang dapat dilibatkan dalam kegiatana analisis kebutuhan. Yang pertama mahasiswa sebagai sumber utama informasi kebutuhan dalam penelitian ini adalah mahasiswa Jurusan Analis Kesehatan yang sudah dan sedang mengikuti perkuliahan Bahasa Inggris. Kedua, dosen yang akan melakukan analisis kebutuhan dan dalam penelitian ini dosen yang dianggap ahli dalam ilmu Analis Kesehatan dan 
telah mengajar dan membimbing di Jurusan Analis Kesehatan. Ketiga, alumni Jurusan Analis Kesehatan yang telah bekerja sesuai dengan pendidikannya, dan telah memiliki pengalaman bekerja sehingga informasi mengenai penggunaan Bahasa inggris dapat diketahui. Secara singkat penelitian ini dilakukan dengan mengikuti alur bagan di bawah ini.

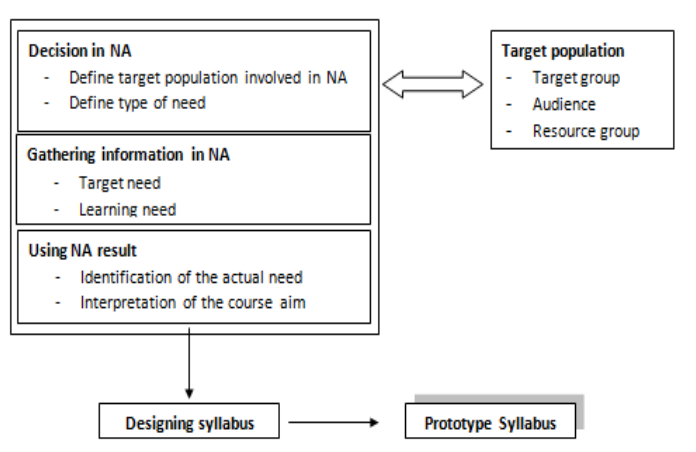

Gambar 1. Alur Bagan

Pelaksanaan Penelitian

\section{HASIL DAN PEMBAHASAN}

Umumnya pengajar mata kuliah Bahasa inggris di Poltekkes kemenkes kendari menggunakan buku teks yang telah tersedia di toko buku seperti English for nurse. Hal ini mudah dilakukan karena telah banyak yang mengkaji penggunaan Bahasa Inggris di jurusan tersebut. Namun bahan ajar Bahasa Inggris untuk tenaga laboratorium kesehatan sangat sulit ditemukan.

Dengan mempertimbangkan bahwa setiap peminatan memiliki ciri dan mahasiswa memiliki kebutuhan yang berbeda maka sangat tidak relevan apabila semua jurusan yang ada di institusi tersebut diajarkan dengan materi yang sama. Situasi ini adalah sebuah tantangan bagi pengajar Bahasa inggris di institusi ini, dan perlu menetapkan suatu tujuan pembelajaran yang jelas pada setiap jurusan yang ada dan disesuaikan dengan kebutuhan mahasiswanya.

Analisis kebutuhan dan konsultasi dengan para pengajar di jurusan perlu dilakukan untuk memperoleh susunan topik yang telah didapatkan. Informasi yang dikumpulkan dalam proses analisis kebutuhan berkontribusi pada isi materi selain dari literature dan materi yang telah dipublikasi dan hasil review hasil ujian matakuliah yang sama, hasil analisis masalah belajar mahasiswa, dan konsultasi dengan pengajar yang ahli dalam jurusan analis kesehatan.

Beberapa penelitian analisis kebutuhan sebelumnya hanya fokus pada satu metode dan dasar teori sehingga kurang maksimal dalam mendeteksi kebutuhan mahasiswa sedangkan dalam penelitian ini menggunakan beberapa teori serta sudut pandang yang berbeda dalam melakukan analisis. Analisis kebutuhan tersebut mencakup beberapa aspek yaitu Analysis target kebutuhan dan kebutuhan belajar yang dikemukakan oleh Hutchinson and Waters (1987) diuraikan dalam tiga aspek, yang pertama yaitu analisis situasi, analisis target kebutuhan, dan analisis situasi pembelajaran. Ketiga bagian analisis tersebut dibahas dalam beberapa poin secara spesifik dalam bentuk kemampuan belajar, masalah belajar, prioritas belajar, sikap belajar, dan solusi (Brown, 1995:43). Struktur seperti ini dibuat untuk memperoleh informasi aktual tentang kebutuhan mahasiswa secara jelas. Langkah selanjutnya adalah menentukan batasan dan urutan kebutuhan mahasiswa sebelum menuliskan silabus. Batasan ini bertujuan untuk menentukan kedalaman dan keluasan 
item pengajaran yang akan dimasukkan ke dalam silabus. Sedangkan urutan menentukan berapa banyak topik yang akan dimasukkan, konten apa yang perlu diberikan lebih awal.

\subsection{Analisis Situasi}

Analisis Situas perlu dilakukan untuk memperoleh pengetahuan awal dari kondisi mahasiswa dalam mempelajari Bahasa Inggris. Dengan melakukan analisis ini, diharapkan dapat ditarik suatu gambaran tentang seberapa jauh kemampuan bahasa yang dikuasai oleh mahasiswa.

Table 1. Kemampuan belajar Bahasa Inggris mahasiswa

\begin{tabular}{clccc}
\hline \multirow{2}{*}{ No } & \multirow{2}{*}{ Level } & \multicolumn{2}{c}{ Mahasiswa } & \multirow{2}{*}{ Category } \\
\cline { 3 - 4 } & & $\mathrm{F}$ & $\%$ & \\
\hline $\mathrm{a}$ & Listening & 59 & $47.88 \%$ & Sedang \\
\hline $\mathrm{b}$ & Speaking & 59 & $25.00 \%$ & Kurang \\
\hline $\mathrm{c}$ & Reading & 59 & $47.88 \%$ & Sedang \\
\hline $\mathrm{d}$ & Writing & 59 & $46.19 \%$ & Sedang \\
\hline $\mathrm{e}$ & Grammar & 59 & $41.10 \%$ & Sedang \\
\hline $\mathrm{f}$ & Vocabulary & 59 & $42.80 \%$ & Sedang \\
\hline $\mathrm{g}$ & Pronunciation & 59 & $41.53 \%$ & Sedang \\
\hline
\end{tabular}

Table 1 Menunjukkan bahwa kemampuan mahasiswa bervariasi; keterampilan speaking $25 \%$ yang dikategorikan kurang. Writing (46.19\%), grammar $(41.10 \%)$ kategori cukup. Selain Speaking, semua aspek kemampuan Bahasa inggris mahasiswa berada dalam tingkatan cukup. Akses yang terbatas dan peluang untuk menggunakan Bahasa inggris di luar kelas dianggap menjadi salah satu faktor yang menjadikan tingkat kecakapan Bahasa mereka menjadi kurang. Oleh karena itu, desainer harus mempertimbangkan kekurangan mahasiswa sebagai prioritas dalam proses pembelajaran atau dengan kata lain, kegiatan kelas yang dapat mengembangkan keterampilan Speaking.

Data di atas sesuai dengan hasil wawancara dengan mahasiswa tentang kemampuan Bahasa inggris mereka.

\begin{tabular}{l} 
"menurut saya belajar Bahasa Inggris \\
kadang gampang kadang sulit, asal punya \\
\hline niat dan semangat serta didukung dengan \\
cara dosen mengajar, Bahasa Inggris bisa \\
menjadi tidak sulit" (Mahasiswa) \\
"menurut saya, belajar Bahasa Inggris \\
susah-gampang, gampangnya sedikit, \\
susahnya banyak" (Mahasiswa)
\end{tabular}

Pernyataan ini juga merujuk pada masalah belajar mereka selama belajar Bahasa inggris

Masalah listening muncul cukup sering, mahasiswa perlu mendengarkan setiap kata secara berulang-ulang, sulit untuk berkonsentrasi, dan hanya dapat mengerti ucapan yang lambat, masalah ini selalu terjadi.

Alasan mengapa speaking masuk dalam kategori kurang muncul dalam presentasi table yang menunjukkan mereka selalu bermasalah dalam penyebutan, takut salah, topik yang tidak familiar, dan kurangnya kosakata serta tatabahasa. Masalah ini menjadi penghalang dalam target tercapainya kemampuan berbahasa inggris. Akan tetapi masalah materi yang tidak relevan tidak selalu terjadi sesuai dengan yang ditunjukkan oleh persentase jawaban alumni, hal ini berhubungan dengan pengalaman mereka belajar Bahasa.

Dapat disimpulkan bahwa masalah belajar mahasiswa yaitu, rendahnya self-confidence, kurangnya kosakata, dan rendahnya pengetahuan tata bahasa yang cenderung terjadi berulang-ulang. Dengan temuan ini maka silabus dan materi ajar harus dapat mengurangi masalah ini. 


\subsection{Analisis Target Situasi}

Menurut Dudley-Evans dan St. John (1998:123), target situasi mencakup tujuan, kebutuhan yang diinginkan dan kebutuhan yang berorientasi pada hasil. kebutuhan yang berorientasi pada hasil ini merupakan tujuan yang ingin dicapai. Informasi kebutuhan mahsiswa analis kesehatan mencakup prioritas belajar, konteks yang spesifik, fitur linguistik, dan keterampilan spesifik. Hasil dan pembahasan dapat dilihat di table berikut:

Table 2. Tujuan mahasiswa dalam belajar Bahasa inggris

\begin{tabular}{|c|c|c|c|c|c|c|}
\hline \multirow{2}{*}{ No } & \multirow{2}{*}{ Tujuan } & \multicolumn{2}{|c|}{ Mahasiswa } & \multicolumn{2}{|c|}{ Alumni } & \multirow{2}{*}{ Rata-rata } \\
\hline & & $\mathbf{F}$ & $\%$ & $\mathbf{F}$ & $\%$ & \\
\hline $\mathrm{a}$ & $\begin{array}{l}\text { Untuk membantu mendapatkan } \\
\text { pekerjaan }\end{array}$ & 28 & $47.50 \%$ & 0 & $0.00 \%$ & $23.75 \%$ \\
\hline $\mathrm{b}$ & $\begin{array}{l}\text { Untuk membantu keberhasilan } \\
\text { pada pendidikan saat ini }\end{array}$ & 13 & $22.00 \%$ & 3 & $30.00 \%$ & $26.00 \%$ \\
\hline c & $\begin{array}{l}\text { Untuk dapat melanjutkan } \\
\text { pendidikan }\end{array}$ & 17 & $28.80 \%$ & 2 & $20.00 \%$ & $24.40 \%$ \\
\hline $\mathrm{d}$ & Untuk berkunjung keluar negeri & 1 & $1.70 \%$ & 0 & $0.00 \%$ & $0.85 \%$ \\
\hline $\mathrm{e}$ & Untuk pengembangan karir & 0 & $0.00 \%$ & 5 & $50.00 \%$ & $25.00 \%$ \\
\hline & $\Sigma$ & 59 & $100 \%$ & 10 & $100 \%$ & $100 \%$ \\
\hline
\end{tabular}

Bagian ini menjelaskan tujuan belajar ESP dan menjelaskan apa manfaat mempelajarinya diwaktu yang akan datang. Dua kelompok responden menunjukkan bahwa mahasiswa belajar ESP untuk dapat membantu pendidikan saat ini $(26.00 \%)$, hal ini juga berdasarkan fakta bahwa salah satu syarat masuk ke perguruan tinggi yaitu mampu menguasai Bahasa Inggris secara aktif maupun pasif. Tujuan lain yang dianggap penting oleh mahasiswa adalah Bahasa Inggris dapat mengembangkan karir (25.00\%), dengan kata lain, menguasai Bahasa inggris dapat menempatkan mereka pada posisi khusus di dunia kerja. Pernyataan alumni juga menguatkan data ini

\footnotetext{
"Menurut saya, belajar Bahasa Inggris membantu sekali karena Bahasa Inggris menjadi utama bagi orang yang mau diterima kerja. Kalau orang yang
}

mempunyai skill lebih, pasti itu yang diterima (bekerja)" (Alumni)

Dari hasil persentase angket dan wawancara, menunjukkan ada kecenderungan mahasiswa belajar ESP dengan tujuan Akademik dan profesi. Menurut Hutchinson and Waters (1987:16), kedua tujuan tersebut dapat direncanakan bersamaan karena pembelajar ESP dapat berasal dari para professional dan akademisi. Oleh karena itu, mahasiswa belajar ESP untuk mengembangkan kompetensi akademiknya dan selanjutnya dapat bermanfaat ketika mereka bekerja sebagai tenaga laboratorium kesehatan.

Informasi ini dapat dijadikan acuan dalam pemilihan topik yaitu topik-topik yang wajib dikuasai oleh mahasiswa sebagai indikator kompetensi keilmuan jurusan analis kesehatan dan topik yang sangat umum dalam dunia kerjanya. Hasil yang diharapkan adalah mahasiswa menjadi fasih dalam komunikasi dan sangat familiar terhadap kosakata dan juga tata Bahasa yang dikembangkan dengan topik-topik tersebut. Lebih lanjut, perlu diketahui jumlah presentase kebutuhan mahasiswa tentang apa yang ingin dicapai dalam mempelajari ESP dengan topik yang spesifik itu.

\subsection{Analisis Situasi Belajar}

Analisis ini perlu dilakukan untuk mengetahui bagaimana mahasiswa belajar, metodologi yang cocok buat mereka, teknik mengajar apa yang menarik, sikap belajar mereka, dan seterusnya. Dengan melakukan analisis ini, peneliti dapat menarik suatu gambaran bagaimana cara mahasiswa belajar yang nantinya dapat membantu pengajar 
menentukan metode apa yang cocok untuk mereka.

Secara umum, aktivitas belajar dengan objek memperoleh response positif dari para responden. Temuan ini mengindikasikan adanya kebutuhan akan aktivitas belajar yang bervariasi. Hutchinson and Waters (1987:139-140) menyarankan untuk mengaplikasikan banyak teknik dalam pengajaran ESP untuk meningkatkan motivasi belajar mahasiswa. Urutan presentase berikut ini menentukan aktifitas apa yang akan menjadi bagian dari silabus ESP yang akan di ajarkan kepada mahasisiwa.

Selanjutnya yaitu Preferensi metode belajar mahasiswa, pada bagian ini bertujuan untuk mengetahui cara belajar yang diingankan mahasiswa agar dapat disesuiakan dengan metode mengajar. Menurut Nunan (2015:159) bahwa pengajaran yang efektif terjadi apabila gaya belajar mahasiswa cocok dengan cara mengajar dosen. Jadi tujuan dari pertanyaan ini adalah untuk mendapatkan informasi tentang metode belajar apa yang diharapkan oleh mahasiswa.

Table 3. Preferensi Metode Belajar Mahasiswa

\begin{tabular}{|c|c|c|c|c|c|c|c|}
\hline \multirow{2}{*}{ No } & \multirow{2}{*}{ Metode } & \multirow{2}{*}{ Opsi } & \multicolumn{2}{|c|}{ Mahasiswa } & \multicolumn{2}{|c|}{ Alumni } & \multirow{2}{*}{ Rata-rata } \\
\hline & & & $\mathbf{F}$ & $\%$ & $\mathrm{~F}$ & $\%$ & \\
\hline \multirow{3}{*}{ a } & \multirow{3}{*}{ Belajar secara individu } & Ya & 43 & $72.90 \%$ & 5 & $50.00 \%$ & $61.45 \%$ \\
\hline & & Tidak & 16 & $27.10 \%$ & 5 & $50.00 \%$ & $38.55 \%$ \\
\hline & & $\Sigma$ & 59 & 1 & 10 & $100 \%$ & \\
\hline \multirow{3}{*}{$\mathrm{b}$} & \multirow{3}{*}{ Belajar secara berpasangan } & Ya & 47 & $80 \%$ & 7 & $70.00 \%$ & $75.00 \%$ \\
\hline & & Tidak & 12 & $20.30 \%$ & 3 & $30.00 \%$ & $25.15 \%$ \\
\hline & & $\Sigma$ & 59 & $100 \%$ & 10 & $100 \%$ & \\
\hline \multirow{3}{*}{ c } & \multirow{3}{*}{ Belajar dalam kelompok kecil } & Ya & 45 & $76.30 \%$ & 9 & $90.00 \%$ & $83.15 \%$ \\
\hline & & Tidak & 14 & $23.70 \%$ & 1 & $10.00 \%$ & $16.85 \%$ \\
\hline & & $\bar{\Sigma}$ & 59 & $100 \%$ & 10 & $100 \%$ & \\
\hline \multirow{3}{*}{$\mathrm{d}$} & \multirow{3}{*}{ Belajar dalam kelompok besar } & Ya & 41 & $69.50 \%$ & 6 & $60.00 \%$ & $64.75 \%$ \\
\hline & & Tidak & 18 & $30.50 \%$ & 4 & $40.00 \%$ & $35.25 \%$ \\
\hline & & $\Sigma$ & 59 & $100 \%$ & 10 & $100 \%$ & \\
\hline \multirow{3}{*}{ e } & \multirow{3}{*}{ Belajar di luar kelas } & Ya & 43 & $72.90 \%$ & 5 & $50.00 \%$ & $57.6 \%$ \\
\hline & & Tidak & 16 & $27.10 \%$ & 5 & $50.00 \%$ & $38.55 \%$ \\
\hline & & $\Sigma$ & 59 & $100 \%$ & 10 & $100 \%$ & \\
\hline
\end{tabular}

Persentase tanggapan yang diperoleh cukup tinggi; yang tertinggi adalah belajar dalam kelompok kecil $(83.15 \%)$, bekerja perpasangan $(75.00 \%)$, belajar dalam kelompok besar $(64.75 \%)$, belajar individu $(61.45 \%)$, dan belajar di luar kelas (57.6\%). Dalam satu situasi belajar satu metode dapat berhasil dibandingkan metode yang lain. Dengan memberikan metode yang bervariasi, rasa bosan yang biasa dirasakan oleh mahasiswa dapat diminimalisir.

\subsection{Perancangan Silabus}

ESP muncul sebagai trend baru yang mencakup tiga alasan utama yaitu perkembangan dunia baru, revolusi linguistic, dan fokus pada pembelajar, (Hutchinson and Waters, 1987: 6-8). Pertama, pertumbuhan teknologi dan perdagangan yang cukup pesat menyebabkan masyarakat berusaha menguasai Bahasa inggris sebagai Bahasa internasional. Mahasiswa belajar untuk dapat memahami buku dan publikasi internasional untuk pengembangan ilmunya. Yang kedua, perubahan dalam linguistik telah mengubah pandangan dalam belajar Bahasa yang sebelumnya dimulai dari menguasai aturan dan tata Bahasa secara umum menjadi belajar Bahasa dalam komunikasi nyata sesuai kebutuhan dengan mengidentifikasi dan menganalisis karakter Bahasa sesuai konteksnya.

Lebih lanjut, ESP juga berfokus pada pengembangan psikologi pendidikan yang berpusat pada pembelajar dimana mereka mempunyai perbedaan kebutuhan dan minat yang berpengaruh pada motivasi belajarnya. Sangat penting bagi pengajar mengetahui minat dan 
kebutuhan ini dengan relevansi materi ajar yang diberikan di setiap pertemuannya. Jika pembelajar adalah tenaga laboratorium kesehatan maka pengajar perlu menyajikan materi dalam konteks tersebut dengan tujuan mereka dapat menggunakan Bahasa Inggris dalam situasi sebenarnya.

Hal tersebut di atas menjadi acuan dalam melaksanakan pengajaran ESP di Jurusan Analis kesehatan Poltekkes Kemenkes Kendari. Dengan ini maka dosen perlu mengetahui dan mengajarkan bagaimana Bahasa inggris digunakan dalam komunikasi sehari-hari di bidang keilmuan dan pekerjaan mereka dengan mempertimbangkan aspek psikologis mahasiswa seperti kebutuhan dan minat belajar khususnya dalam pemilihan metode, strategi mengajar dan penyusunan bahan ajar dengan melakukan suatu analisis kebutuhan.

Merangkum dari hasil temuan Analisis situasi, analisis target, and analisis situasi belajar, Rosset, 1982 yang dikutip dalam in Brown (1995:43) membagi kebutuhan kedalam lima kelompok yaitu masalah belajar, prioritas belajar, kemampuan belajar, sikap belajar, dan solusi belajar.

Peneliti

kemudian memformulasikan tujuan belajar. Tujuan ini diformulasikan untuk memberikan definisi jelas tentang tujuan suatu program pembelajaran, sebagai petunjuk bagi dosen, mahasiswa, dan penulis materi ajar, dan mejadi fokus pengajaran (Richard, 2001:120).

Jenis silabus yang direkomendasikan dalam penelitian ini adalah layer silabus atau integrated syllabus. Ini dilakukan jika konten kebutuhan mahasiswa lebih dari satu jenis silabus berdasarkan hasil analisis kebutuhan (Brown, 1995:12). Cakupan dan urutan isi pembelajaran yang disesuaikan dengan alokasi waktu dapat dilihat pada table berikut.

Tabel 4. Batasan dan Urutan Konten Mata Kuliah

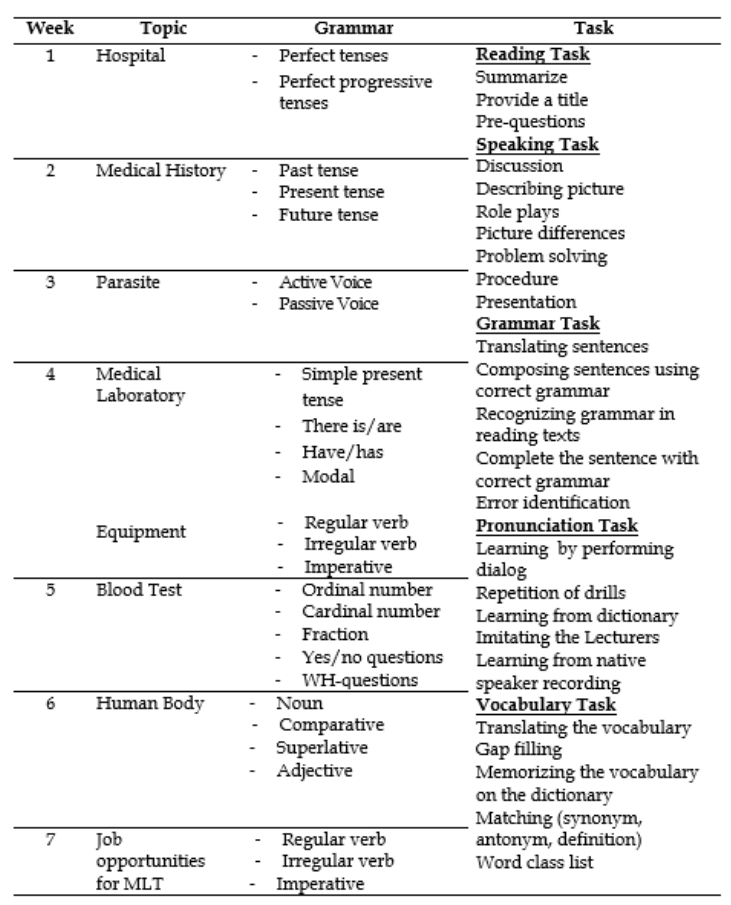

Batasan dan urutan materi ini akan menjadi isi dari silabus yang akan di rekomendasikan pada jurusan analis kesehatan. Selanjutnya isi silabus direalisasikan dalam kegiatankegiatan pembelajaran dalam kelas yang tersusun dalam unit. Kumpulan unit-unit ini disusun dan disajikan ke dalam bahan ajar.

\section{KESIMPULAN}

Informasi yang lebih akurat mengenai kebutuhan mahasiswa diperoleh melalui pemberian angket dan wawancara semi terstruktur kepada mahasiswa, alumni, dan dosen. Data dianalisis dengan menggunakan metode kuantitatif dan kualitatif. Hasil penelitian ini 
menunjukkan bahwa silabus perlu dirancang berdasarkan pada pengembangan akademik dan profesi yang berfokus pada konteks Analis Kesehatan. Isi silabus berdasarkan analisis kebutuhan menyajikan aspek keterampilan membaca dan berbicara serta penggunaan tata Bahasa yang digunakan sesuai dengan topik kesehatan. Isi silabus disajikan dalam rangakian aktivitas pembelajaran variatif yang mampu memberikan kemudahan dalam proses pembelajaran dan pemerolehan Bahasa di dalam kelas. Demikian pula materi ajar dirancang dengan mempertimbangkan integrasi dari tujuan, keterampilan, topik, tata Bahasa, dan aktivitas untuk menghubungkan kesenjangan antara pengetahuan awal mahasiswa dan pengetahuan yang dibutuhkan untuk tujuan akademis dan profesi di masa depan.

\section{DAFTAR PUSTAKA}

Richard, J. C., \& Schmidt, R. (2010). Longman dictionary of language teaching and applied linguistics. (4th ed). Harlow: Pearson Education ltd.

Brown, J.D. (1995). The Elements of Language Curriculum: A Systematic Approach to Program Development. Boston: Heinle \& Heinle Publishers.

Hutchinson T. \& Waters, A. (1987). English for Specific Purposes: A Learning-centered Approach. Cambridge: Cambridge University Press.

Dudley-Evans, T., \& St. John, A. M. (1998). Developments in English for Specific Purposes: A MultiDisciplinary Approach.
Cambridge: Cambridge

University Press.

Nunan, D. (2015). Teaching English to speakers of other languages: an introduction. New York:

Routledge. 